\title{
ICT Standardization and Innovation Change: Case of ISO Consensus Standardization
}

\author{
Masami Kajiura*
}

Submitted: Aug. 8, 2013; Accepted: Oct. 24, 2013; Published Online: Nov. 1, 2013

\begin{abstract}
This paper clarifies the change in international technology standardization as a change in innovation. The change comes to be shown in how to take the consensus standard. The tendency to standardize the systematized concept is a rather arduous and complex endeavor. This paper focuses on Mitsubishi Electric Corporation as such a case. The results interpreted from the approach of closed innovation, open innovation, and social innovation. The following findings are clarified by. 1) The consensus standardization is open innovation in which the enterprise creates value. 2) When the value creation is large, the possibility of the maximization of such value capture that achieves the earnings acquisition can be improved. 3. The innovation of the consensus standardization is reciprocal for the stakeholder. The possibility for open and social innovation to supplement the success in innovation mutual and to achieve an effect is suggested.
\end{abstract}

Keywords Open innovation, closed innovation, social innovation, consensus standardization, smart community, Mitsubishi electric corporation, DMIC

\section{Introduction}

The enterprise is an important supporter who helps form, maintain and develop society. Recently, a study on innovation linked social change and corporate business, and found that innovation is effective as a useful tool for the change of the society, although the ultimate goal of corporate business is in the hunt for profit. Delving into innovation research in which both types of innovation (open and social) coexist needs clarification. Innovation that presses growth and the development of a corporate business is open innovation whereas social innovation is innovation which brings about social change. The former is an idea of corporation using outside knowledge to achieve profit and the latter is an idea to try to achieve social change within corporate business

\footnotetext{
*Faculty of Business and Commerce, Aichi-Gakuin University, Japan; msmkj@dpc.agu. ac.jp
} 
and society. Therefore it is necessary to clarify not only reviving social change and profit attainment, but also to clarify how this can be achieved through innovation. However, such a relationship has not clearly been shown in previous studies. Looking international standardization of ISO cases may provide some insight while standardization was in declined as private enterprise established the de facto standard. Formal standardization assumes stake holders settle on consensus to gain power. After WTO approval, formal standardization has been growing in the global market. Therefore, there is a possibility that target markets can be maximized if enterprises use formal standards. Value creation and value capture in innovation are clarified in this paper. For this paper's aim is to ultimately find the point of contact between open innovation and social innovation.

\section{Analytical Approach}

This case study is based on information and materials obtained from MEC, CLPA related companies and ISO/IEC members. Data comprise interviews conducted from 2005 to 2013 over a period of 29 times. The author did the innovation case analysis on many elemental technologies. Three case analyses on MEC have been finished in the average. CC-Link is one of the typical cases described in this paper. This case is compared with the DMIC case, and the difference in innovation is clarified. The literature review concerning three innovations is done (II), and the analysis framework is set (III). Afterwards, the comparison analysis works three consensus standardization cases relating to MEC (Mitsubishi Electric Corporation) (IV). Then, how the level and design of standardization influences the innovation formation is clarified. (V, VI).

\section{Literature Review}

\section{Standardization Trend}

De fact standard is a reason why enterprises lose strategic effectiveness today (Kajiura, 2011; 2012a; 2012b). De jure standard, which allows stakeholders to confer and decide, has become an effective replacement of the de fact standard. This dynamic produced an independent concept and definition named the "consensus standard" (De Vries, 1999: 6). This standard method is a standard decided by the stakeholder's strategic cooperation (Shintaku and Etoh, 2008; Tokuda et al., 2011; Kajiura, 2013). 
Table 1 Issued international standard by Japanese corporation proposal

\begin{tabular}{|c|r|r|r|}
\hline Year & De facto standard & De jure standard & \multicolumn{1}{c|}{ Total } \\
\hline $1995-2000$ & $158(68.7 \%)$ & $72(31.3 \%)$ & 230 \\
\hline $2001-2006$ & $93(49.5 \%)$ & $95(50.5 \%)$ & 188 \\
\hline Total & 251 & 167 & 418 \\
\hline
\end{tabular}

Source: Takeda (2008: 44)

The de facto and de jure standards have changed. The de facto standard has decreased in the ICT field and the de jure standard has increased (Table 1). A standard can be decided by a consortium or a forum in electronic and electric machine fields (Takeda, 2008). The de jure standard is decided after all increases are complete. The pre-eminence of a public standard in the market progressed due to easing of the system by international standardization organizations (Etoh, 2007; 2008; Kajiura, 2010; 2012a; Fujii, 2012). The change in this standardization is influenced by the change in industrial structures. A huge number of venders with vertical integrated structures have declined, especially in the ICT industry. Industrial structures shifted to the horizontal distribution type or vertical distribution off-line system from which the enterprise of the specialized field made the network. The vender enclosed the user with the product using an original standard. However, industrial structures changed and such a strategy has changed the strategy for open networks. Such a change means that a vender's power is relatively made a weakness, and a user's power has become strength. In other words, not only the vender but also various users take part in a standard formation. The number of stakeholders has also increased. A formal standard conforms to WTO Agreements (TBT: Agreement on Technical Barriers to Trade, GPA: Agreement on Government Procurement). Due to the WTO/TBT and WTO/GPA agreements, the de jure standard has increased and became powerful (Shintaku and Etoh ibid, Kajiura ibid). WTO members are obligated to promote the international standardization to eliminate trade barriers, to make local standards, emplace restrictions, and enforce regulation which conforms to the international standard. Therefore, when neither the product nor service agrees with a formal standard, the potential to be lawfully excluded from the international market becomes a possibility.

The ICT technological system is an accumulation of various elemental technologies by a lot of intricacies. To secure interoperability and interfacibility between these element technologies, standardization is needed. In standardization, there is a necessity for forming the mutual agreement between lots of stakeholders. When relating to standardization of social infrastructure, it gives priority to not the de facto standard, which is based on self-interest but 
rather to the public, thus leading to the de jure standardization. Consequently, the possibility that the target market is maximized rises with formal standardizing. In other words, a formal standard has a big impact affecting the global marketplace along with the promotion of the WTO free trade policy. That is, the possibility of not only the aforementioned but also social change brought on by standardization. Even if an enterprise acquires the de facto standard, because of environment changes and market control, it becomes impossible to construct a dominant competitive business model (Yamada, 1997; Shibata, 2000). Cargill $(1989,1997)$ discussed open systems and the ICT consortium. Jakobs $(2000,2005)$ studied standardization decision processes and standardization comprehensive bodies as part consensus standard studies. Kajiura (2005, 2013) and Shintaku and Etoh (2008) outlined the consortium from the standpoint of how international business treats standardization. These studies detail the de jure standardization process by a conference of interested parties in the consortia. This conceptualization is called "the consensus standardization". These studies discuss competition and strategy case studies on consensus standardization introduced by the dominant business model. The model was constructed by the de jure standardization instead of the de facto standardization.

\section{Innovations}

\subsection{Closed Innovation and Open Innovation}

The open innovation theory is an idea that develops the idea of Teece (1986). According to Teece, it has long been known that patents do not work in practice as they do in theory (Teece, 1986: 287). When the patent has weak appropriability, complementary assets are necessary. This notion suggests reinforcement of weak point(s) and construct competence is clarified, suggesting an important notion for the competing domination of the innovation. The idea of appropriability values resources and the original ability that the enterprise accumulates internally is due to "inside approach". This is related to the business model concept of searching from the inside of the organization. When the resources an enterprise has are weak appropriability, outside procurement becomes necessary. This idea is exemplified by the open innovation theory. The open innovation theory of Chesbrough (2003) shows how the enterprise should create the innovation.

Closed Innovation is also described by Chesbrough. The assumption of the closed innovation model says that successful innovation requires control and ownership. A company should control the creation and management of ideas by itself. A company decides to run their own research and development units. The entire new product development cycle should be integrated within the 
company where innovation is performed in a closed and self-sufficient way. The 1980s was the era of closed innovation and internal R\&D. Many R\&D departments of private companies were at the leading edge of scientific research. The setup of internal $\mathrm{R} \& \mathrm{D}$ was perceived as a strong barrier for new comers, as large investments had to be made to be able to compete.

On the other hand, open innovation is a paradigm that assumes that firms can and should use external ideas as well as internal ideas, and internal and external paths to market, as the firms look to advance their technology (Yoon and Lee, 2010; Moon, 2011). The central idea behind open innovation is that, in a world of widely distributed knowledge, companies cannot afford to rely entirely on their own research, but should instead buy or license processes or inventions such as IPR from outside resources. The viewpoint of an open innovation that pays attention to the introduction and the emission of the innovation element are dynamic. Chesbrough (2006) described that an open innovation is important to business model building. It is described that open innovation is a means that value creation (make to the creation) and value capture (make to earnings). The multinational company has constructed dominant competence by having organizational structures of the vertical integration type and actively used internalization until the mid-20th century. However, situations changed, and the structure of the vertical separation or the horizontal distribution type came to compete for dominance in the latter half of the 20th century. This is a conversion from closed innovation to open innovation, and the paradigm shifted in innovation according to Chesbrough (2003). The former is traditional innovation and the in-house production type of $\mathrm{R} \& \mathrm{D}$ putting the new product on the market by oneself and obtaining earnings. Closed innovation is losing one's edge due to the environmental change of stiffer market competition and the needs of speedier R\&D. The latter is an innovation that uses the ideas within the enterprise and outside of the enterprise (other companies). It is to unite inside and outside ideas organically and to create value. To begin with, the enterprise that can achieve an open innovation retains organization capability that rearranges knowledge management (Teece et al., 1997). Moreover, a highly capable corporation retains integration capability for value creation (Chesbrough and Appleyard, 2007). In many instances, open and closed innovation can be seen in multinational companies where knowledge and technology are essential to staying competitive. However, innovation can also have another facet, namely how to use said innovation.

a) Flow and Direction

Open innovation effectively makes use of knowledge and the technology that exists in-house and outside the company. Whereas, closed innovation makes all things in-house. Additionally, open innovation tries to catch 
innovation from two directions. Knowledge and technology are input from outside the company to in-house when the innovation process is opened and output from in-house to outside the company occurs at the same time. Outsidein flow is in the former, and the latter is inside-out flow (Chesbrough, 2006). Chesbrough (2006) describes a case on Dell Computer about the former and a corporate case with Xerox is described about the latter. For instance, external technology is introduced by M\&A and corporate R\&D, etc. about the outsidein in the enterprise (Chesbrough and Garman, 2009; Enkel et al., 2009; Hong, 2012). Moreover, the sale and the licensing of IPR are inside-out. When both inside-out and outside-in are synchronal, it is assumed to be the coupled type.

\subsection{Social Innovation}

a) Social Change and Market Building

Social innovation is a type of innovation accomplished by coexisting with the social revolution strategy and the stake-holder strategies of the enterprises and the group (Mumford, 2002; Goldsmith et al., 2010; Saul, 2011; Nicholls and Murdock, 2012). First of all, Schumpeter (1912) addressed the process of social innovation directly with his theory of creative destruction. Social innovation is a new strategy that meets social needs of all kinds that extends and strengthens our society. Social innovation can take place within government, the profit sector such as corporations, NPOs, or in the spaces between them. Social innovation creates many types of platforms needed to facilitate such cross-sector collaborative social innovation. And the enterprise assumes social innovation to be a machine and (tool) to newly revive business. Social innovation is not corporate social responsibility and philanthropy. Social innovation creates value for the social capital market. Then, the acquisition of a sustainable economic return for the enterprise might become possible. For instance, a lot of enterprises are reviving a social revolution in cooperation with NPOs (Kotler and Lee, 2009; London and Hart, 2011; Saul, 2011). If the poorest socio-economic group such as BOP (Base of Pyramid) is included, the potential market scale that a social revolution creates is estimated to be trillions of dollars (Saul, 2011: 7; Prahalad, 2005). Many cases show a common theme. Big scale social change comes from better cross-sector coordination rather than from the isolated intervention of individual organizations. Effectiveness of this approach is still limited, but these examples suggest that substantially greater progress could be made in alleviating many of our most serious and complex social problems if nonprofits, governments, businesses, and the public were brought together around a common agenda to create collective impact (Kania and Kramer, 2011). In the competitive strategy theory, there is research that points out the market potentiality of a social innovation (Porter and Kramer, 2011). Society's needs are huge-health, better housing, improved nutrition, 
help for the aging. They are the greatest unmet needs in the global economy. The purpose of the corporation must be redefined as creating shared value, not just profit. This will drive the next wave of innovation and productivity growth in the global economy. It will also reform capitalism and its relationship to society (Porter and Kramer, 2011).

\section{b) Condition for Success}

Success in social innovation is not easy. First of all, it is difficult to revive a social revolution. Moreover, both social revolutions and corporate businesses should succeed. Stakeholder-organizations have attempted to solve social problems by collaboration for decades without producing viable results. The vast majority of these efforts lack the elements of success that enable collective impact initiatives to achieve a sustained alignment of efforts (Kania and Kramer, 2011: 39). Successful collaboration initiatives have five key conditions that together produce true alignment and lead to powerful results: a common agenda, shared measurement systems, mutually reinforcing activities, continuous communication, and backbone support organizations (Porter and Kramer op. cit.). It is not easy to tie to corporate profits meeting such requirements. Success factors and coexistence with social innovation in business is clarified from some cases. Saul suggests that the establishment of profitable business through social innovation explains the fundamental shift in the role of business in society from social contract to social capital market as follows (Saul, 2011: part II). He identifies the 5 social innovation strategies: submarket products and services, social points of entry, pipeline talent, reverse lobbying, and emotive customer bonding, and offers step-by-step guidance for creating economic value through positive social change. Kania and Kramer shows that successful collective impact initiatives typically have five conditions that together produce true alignment and lead to powerful results: a common agenda, shared measurement systems, mutually reinforcing activities, continuous communication and backbone support organizations.

\section{c) Prime Opinion Leader}

Social innovation does not have fixed boundaries (Murry et al., 2010: 3). There are many stakeholders in many contexts. It happens in all sectors: public, NGOs and private. Therefore, a prime opinion leader of the innovation is sometimes an enterprise (provider), it is sometimes a consumer (user), and it is sometimes a mediator (NGO) (Murry et al., 2010: 3, Nicholls and Murdock, 2012: 11) (Figure 1). 


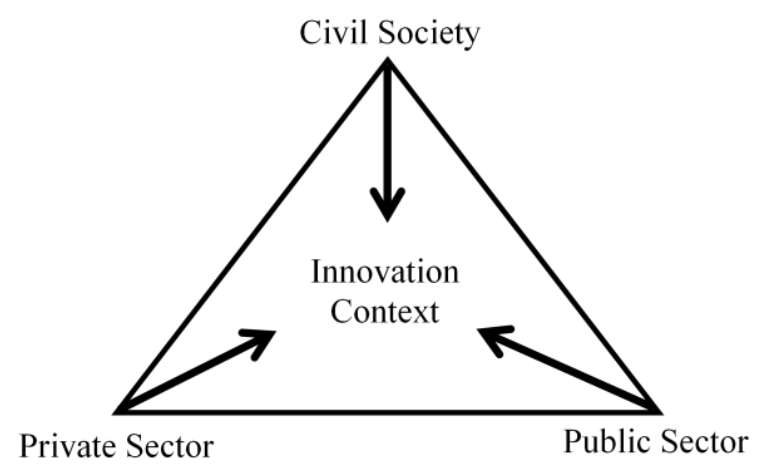

Figure 1 Social innovation as boundary

Source: Nicholls and Murdock (2012: 11)

\subsection{Closed Innovation and Open Innovation and Social Innovation}

In figure 1 the author describes innovation and standards. Until recently, the relationship between the innovation and the standards that the author described has been arranged. The de facto standard is a standard that a dominant enterprise to compete makes the market share an oligopoly as a result of market competition. A typical enterprise can maintain the vertical integration type. And, the enterprise is in-house making knowledge and the idea by itself. Such a type can be considered as closed innovation. When the enterprise obtains the de facto standard, it is possible to achieve success in a closed innovation or open innovation system. With the vertical integration type, the enterprise has completely monopolized the market and the technology is developed by itself. And the enterprise standardizes the technology as the de facto standard. In this case, it is closed innovation. When the technology and the patent are purchased from the other companies, it is an open innovation.

However, it is likely to change to a closed innovation after M\&A is done as a purpose that the enterprise strengthens a specific business. The enterprise that makes the market an oligopoly holds not an open innovation in the business field but really a closed innovation. On the other hand, the consensus standard is decided depending on stakeholders. Knowledge and information are exchanged in the process of the decision. Moreover, final consensus building is necessary for this method. Therefore, this type is considered to be an open innovation. Then, how does it relate to social innovation? It is a difference within the range from the number of stakeholders. The focus of open innovation is a single corporate organization. It exchanges resources with an external enterprise and revives the innovation. Moreover, it is assumed to be a main target for creating the business model. Moreover, open innovation distinguishes value creation and value capture, and lucidly discusses the 
innovation formation process. However, the number of stakeholders that takes part in an open innovation at a corporate level is limited. On the other hand, the down shot works down through societies and markets to a social innovation. When a social innovation is assumed, a lot of stakeholders in society take part. If the consensus standardization is advanced by a lot of stakeholders, it is an interesting point of consideration as to its influence on social innovation.

The potential market formed by solving the problem of world poverty is emphasized. Cases with the multinational company are shown as a succeeding case. However, many of these organizations are still only in the developing stages at best with intermediate results. Effectiveness of the social innovation approach is still limited and it is difficult to create collective impact (Kania and Kramer, 2011: 38). The social capital market is also increasingly driving significant profits with products that promote positive social and environmental change (Saul, 2011: 5). But the market did not appear overnight. It has been developing and maturing over the last thirty years (Saul, 2011: 7). However, research is indefinite on the distinction between value creation and value capture of the innovation process. Therefore, requirement for the innovation success is cramped and guessing which stage is effective is difficult to gauge (Table 3). Whether it is effective in the value creation stage or the success requirement or effective in the value capture stage is not shown. Generally, it is valued that the social innovation theory presents the future possibility for the potential value of the market, that is, the value creation. However, the theory is not deeply discussed in the making of a corporate business, in a word, the value capture - earnings. There is a reason why the open innovation theory analyzes value capture in detail. Because this theory originally focuses on the enterprise organization, it searches for its own specific business model. It is thought that a social innovation is achieved by those interactions. This is an interface for open innovation and social innovation to meet. If such is the case, then it is necessary to apply the focus to the dynamism of the innovation formation process. It is necessary to clarify the role, the function, and the interaction of the organization and the group. In addition, it is necessary to distinguish the stage of the value creation and the value capture. 


\section{Framework}

\section{Innovation Phases: Value Creation and Value Capture}

Innovation is based on combination (Schumpeter, 1912). There are phases and modes of combination (Hong, 2012; Herzog, 2008; 2011). There are two phases in the process where an open innovation is achieved (Chesbrough, 2003). The closed innovation business model structure is limited and static (Kajiura, 2010; 2012a; 2012b). However, the probability of success of the business increases because an open innovation source can introduce directionality, knowledge and resources from the outside during various stages of the process (Chesbrough, 2006: 3). They are the value creation and the value capture. The former is the generation phase of the innovation and the latter is a phase of tying earnings to the economic value of the service and product as marketed. That is, the former is a stage where a dominant innovation to compete is created and the latter means the stage where earnings are obtained. In the entire innovation, the value creation and the value capture are different phases, and the former can be achieved by using the idea and the knowledge that is in-house and outside the company. Moreover, the latter establishes a dominant business model for the enterprise to compete (ibid). That is, it is clarified that in the innovation, these two phases exist. This is a reply to answer the question on why the above-mentioned innovation is not related to earnings. This concept shows that the generation of the innovation and making the innovation earnings are different stages.

There are some common types to both stages. Consensus standardization is a process where the enterprise confers de jure standardization on the interested party and the standard is settled. Various ideas and knowledge are accumulated in this process, which is considered to be the value creation process of innovation. The economic value (earnings) does not necessarily materialize the innovation from the previous research in this process. It is realized in a subsequent process, and the innovation element of value capture is found. How are idea and knowledge introduced and emitted in value creation and value capture? In open innovation research, cases might be emitted from the directionality of idea and knowledge, that is, from an external enterprise and from outside an enterprise within it has been discovered. To clarify directionality, the analysis from such an aspect will be needed in consensus standardization. Vertical integration and closed innovations of the internal production type and open innovations of the vertical off-line type use the idea and knowledge of other companies. The creation and development of innovation might not be achieved in the same organization and may be achieved because of the relationships between organizations. Various internal 
and external innovation elements are introduced. Furthermore, the process combines and constructs the business model (innovation task partitioning). Therefore, it is necessary to focus on value creation and value capture in consensus standardization and clarify the role of innovation in task partitioning. Finally, the idea and knowledge might be opened to the public (open policy), hidden or may not be open to the public (closed policy). How do open and closed policies influence value creation and value capture in consensus standardization? (Table 2)

Table 2 Innovation type matrix

\begin{tabular}{|l|l|l|}
\hline & \multicolumn{1}{|c|}{ Value creation stage } & \multicolumn{1}{c|}{ Value capture stage } \\
\hline Innovation & Open / closed innovation & Open / closed innovation \\
\hline $\begin{array}{l}\text { Directions of } \\
\text { knowledge, idea }\end{array}$ & $\begin{array}{l}\text { Outside-in / Inside-out flow } \\
\text { * Both is called coupled type }\end{array}$ & $\begin{array}{l}\text { Outside-in / Inside-out flow } \\
\text { * Both is called coupled type }\end{array}$ \\
\hline Policy & Open / closed policy & Open / closed policy \\
\hline
\end{tabular}

\section{Cases: Consensus Standard}

\section{Standard System as Composite}

The standard is a complex system composed by a lot of elements. Up to now, the systematization of the standard has been arranged by conceptualizing, and by typology and hierarchizing (Verman, 1972; Sanders, 1972; De Vries, 1999). They are the systematizations of three dimensions like (1) hierarchical level (from the enterprise, located in the subordinate position dimension to nation, located upper rank dimension), (2) aspect (qualitative content of the standardization of the product, the technology, the testing method, and the code, etc.), and (3) subjects (fields of the standardization of electricity, the machine, and the communication, etc. and areas), etc. (Verman, 1972). The standard system is hierarchized by a conceptual size. The system is composed of the upper rank, medium rank, and lower rank. There are inclusive and are common concepts within the upper rank, and is a concept to support the upper rank in the subordinate position. An upper dimension is a big dimension at the international level and at the policy level etc. A more detailed element standard that supports an upper standard is located within the middle and reaches downstream of the system. The lower subordinate position standards are concrete, local systems and technologies. Such a standard system is considered to be standard if the total composite is done. If a large, wide upper standard is 
planned, and the figure of a big composite standard is settled on, a potential impact that influences the international marketplace society grows (Figure 2).

The consensus standardization is being operated by many stakeholders who relate to these dimensions. De Vries shows that many stakeholders take part in the formation process of the consensus standard. The provider (producer) and the user can greatly divide stakeholders (De Vries, 1999: 24-29). In general, the number of users is more than that of the provider. Because of many cases, the provider is often located in the composite standard upper rank. If the standard number of users located in the subordinate position is maximized, the market grows. If the provider enterprise can acquire an upper ranking standard, it might become possible to rule the entire standard composite including the subordinate position standards as exclusive. The related market can be maximized by obtaining at least a lot of users. Even if the market share is divided with each other users, the possibility that a promising business strategy to materialize is high, if the provider can acquire an upper ranking standard. Next, the author will attempt to verify how MEC (Mitsubishi Electric Corporation) underwent such standardization.

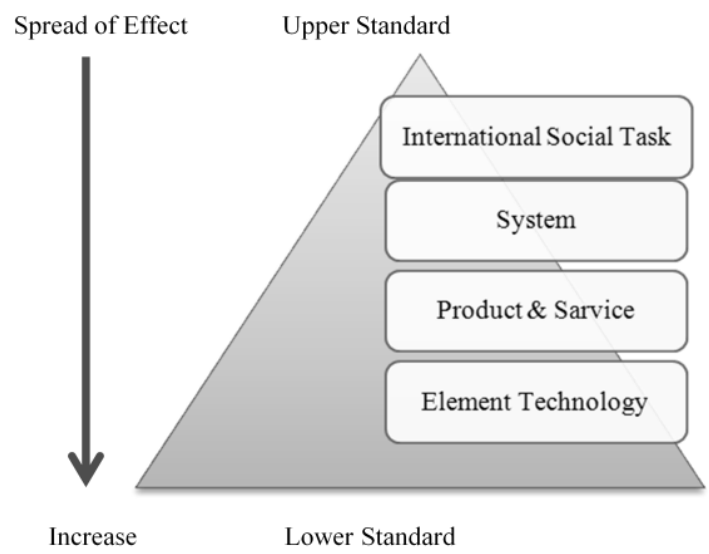

Figure 2 Composite Standard Pyramids

\section{MEC: Subordinate Position Standardization}

MEC is a manufacturer of electric appliances which ranges from consumer goods to space satellites. MEC was established on January 15, 1921, and belongs to the Mitsubishi Group. MEC is a rather large player in the electronics market taking third place in total sales in the industry after that of Hitachi and Toshiba. The author investigated the international standardization in the lower subordinate rank that this company had done so far (Kajiura, 
2012a; 2012b; 2013). The next portion introduces the outline of a typical case (ibid).

\subsection{CC-Link}

As part of ICT, factory automation (FA) field networks are currently widespread in the production plant to conserve wiring. CC-Link is such a network technology. The network is segregated by the information content that flows to the service space and the network. Information is exchanged between network hierarchies. FA systems comprise sets of equipment that many enterprises offer. Therefore, the network is made open as a public service, which benefits interested enterprises. The field level network is the fastest network to control devices in the level. This network comprises of a programmable logic controller (PLC) as the controller. The PLC substitutes the relay circuit and various field equipments that are coupled. This technology is an interface technical standard to which the international standard is enacted in the ISO and IEC. The electric motor was a key model in the FA business until mid-1960. Mechatronics and the FA machine control business then became mainstays after the high growth period of Japan. Few enterprises can construct a complete system with in-house products. Thus, the FA industrial structure has changed from the vertical integration type to the vertical and horizontal off-line systems. The CC-Link technology that couples element equipment of each company is open to the public. MEC developed the network technology that connects a terminal robot with a controller, which is used in its own production line. It acquired a patent for it in four countries (network systems for a programmable controller: 3343036/Japan, 5896509/USA, 246906/Korea and 19650753/Germany). MEC opened the basic company standard and released this programmable controller to the public in 1996. In November 2000, the CC-Link Partner Association (CLPA) was established to spread this standard.

CLPA is responsible for managing the popular FA field network, CC-Link. MEC became a leader by opening its own technology to the public with the help of six member companies: MEC, NEC, IDEC, Cognex, 3M and Digital. The joining members originally comprised 134 companies. As of fiscal year 2010, CLPA now comprises 1,500 members, with 1,130 products and eight million nodes (number of connections). The share of CC-Link in Asia is the largest (40\%). Members enjoy privileges such as obtaining licensing technologies and specifications connected directly with the business and conducting the obligatory conformance examination for a fee. The conformance examination is an authentication system that is mandatory for CC-Link products. The spread of CC-Link as an international standard was attempted in foreign countries. Therefore, CLPA proposed the standard to the Semiconductor Equipment and Material International (SEMI, USA), a worldwide semiconductor fabrication equipment group comprising 2,500 companies. 
SEMI establishes the networking protocol for semiconductor fabrication equipment. CC-Link was adopted as an industry standard through the examination in May 2001 (SEMI standard E54.12). In addition, CLPA advanced the de jure standardization of CC-Link. The international standard of the FA network comprises two forms. The first is the procedure and the data format exchanged between equipment, that is, protocol specification. The second is the specification of the connected equipment (maker and support point, etc.), that is, device profile. The former was standardized as IEC61158 in IEC/SC65C in December 2007, and the latter was standardized as ISO15745-5 in ISO/TC184 SC5 in January 2007. The patent of MEC that relates to these standards is open to the public for free.

CLPA expansion has contributed to the development of the FA business of MEC. Competitors such as Siemens and Rockwell International were skilled in the business of vertical integration and had many product varieties. Thus, their complete system sales were large. However, MEC specialized in principal occupation equipment sales, such as controllers and servo motors (high-speed, efficient driving force), and could not achieve systematic sales with a high additional value. In addition, after the FA networks in Europe and USA named PROFIBUS and Device Net were open to the public, MEC found itself in a difficult position. It wanted to open CC-Link to the public, standardize it as a company standard and spread it. Consequently, it established CLPA.

When network users such as vendors unite the complete system, programmable controllers, such as sequencers take advantage of MEC and widely adopt servo motors. Thus, the spread and the expansion of CC-Link contribute to the business performance of MEC.

\section{New Trend: Upper Rank Standardization}

\subsection{ISO Cases}

Next, the author will delve into cases which use the new consensus standard. The acquisition strategy of an upper ranking standard is working in the consensus standardization. (Ichikawa, 2013a; 2013b). Recently, the Technical Committee (TC) that intends upper ranking standardization is established in the international standardization organization (Table 3). 
Table 3 Upper standard of ISO/TC

\begin{tabular}{|c|c|}
\hline $\begin{array}{l}\text { Technical / project } \\
\text { committee (year) }\end{array}$ & Scope and Business Plan \\
\hline TC 223 social security (2011) & $\begin{array}{l}\text { In recent years there have been many highly consequential natural } \\
\text { and man-made disasters. These incidents have demonstrated that } \\
\text { organizations must prepare themselves, individually and } \\
\text { communally, to prevent and minimize, control and manage the } \\
\text { adverse consequences of these incidents. }\end{array}$ \\
\hline $\begin{array}{l}\text { TC } 224 \text { service activities } \\
\text { drinking water supply } \\
\text { systems and wastewater } \\
\text { systems -quality criteria of } \\
\text { the service and performance } \\
\text { indicators (2008) }\end{array}$ & $\begin{array}{l}\text { ISO/TC } 224 \text { has been developing standards providing guidelines for } \\
\text { service activities relating to drinking water supply systems and } \\
\text { wastewater sewerage systems. }\end{array}$ \\
\hline $\begin{array}{l}\text { TC } 247 \text { Fraud } \\
\text { countermeasures and } \\
\text { controls (2012) }\end{array}$ & $\begin{array}{l}\text { The fraudulent acts take on many forms and are ever changing to } \\
\text { provide the greatest economic return or shift social and cultural } \\
\text { values. The work of this committee will seek to mitigate the effects } \\
\text { of those acts by creating international standards in this area. }\end{array}$ \\
\hline $\begin{array}{l}\text { TC 26o human resource } \\
\text { management (2011) }\end{array}$ & $\begin{array}{l}\text { Standardization in the field of human resource management, to } \\
\text { develop standards that stay current and evolve as the human } \\
\text { resource management evolves, to develop standards that make the } \\
\text { best possible use of available evidence based research etc. }\end{array}$ \\
\hline $\begin{array}{l}\text { TC } 262 \text { risk management } \\
\text { (2011) }\end{array}$ & $\begin{array}{l}\text { Standardization in the field of risk management is responsible for } \\
\text { the TC input to the formulation of a strategy for standardization in } \\
\text { Risk Management through a broad consultation with relevant } \\
\text { stakeholders. }\end{array}$ \\
\hline $\begin{array}{l}\text { PC } 272 \text { forensic sciences } \\
\text { (2012) }\end{array}$ & $\begin{array}{l}\text { Standardization in the field of forensic sciences: The scope of this } \\
\text { committee is aimed at setting particular criteria around which the } \\
\text { consumables used in forensic DNA collection and analysis should } \\
\text { be manufactured. }\end{array}$ \\
\hline $\begin{array}{l}\mathrm{TC}_{2} 68 / \mathrm{SC}_{1} \text { smart } \\
\text { community infrastructures } \\
(2012)\end{array}$ & $\begin{array}{l}\text { Standardization in the field of smart community infrastructures } \\
\text { include basic concepts to define and describe smartness of } \\
\text { community infrastructures as scalable and integral systems, } \\
\text { harmonized metrics for benchmarking, usage of the metrics for } \\
\text { application to the diverse types of communities. } \\
\text { The proposed standards will focus on technical aspects of } \\
\text { community infrastructures including energy, water, transportation, } \\
\text { waste and ICT that support the operations and activities of } \\
\text { communities. }\end{array}$ \\
\hline
\end{tabular}

Source: ISO web site; http://www.iso.org/iso/home/standards_development/list_of_iso_tec hnical_commitees/iso_technical_committee.htm?commid;http://isotc.iso.org/liveli nk/livelink/fetch/200o/2122/687806/customview.htm l.func=ll\&objId=687806\&obj Action $=$ browse \&sort=name Ichikawa, Y. (2013) World Environmental Standardization War, http://business.nik keibp.co.jp/article/report/20130108/241962/2013/4/25 access 
Standardization of an international, social problem is done by the TC, and not just the standardization of the elemental technology but the entire composite system is made a target. The upper standard refers to international social problems in the upper rank and the respective subordinate position. That is, it is considered the composite standard to aim to revive the dealt innovation in the social task. On the other hand, it has the possibility of becoming an open innovation that obtains the business opportunity for a corporate business. ISO states officially, "Standards, for business, are strategic tools that reduce costs by minimizing waste and errors and increase productivity. They help companies to access new markets, level the playing field for developing countries and facilitate free and fair global trade" (ISO web site, 2013).

\subsection{ISO TC268/SC1 Smart Community Infrastructures}

Next, looking at the TC268/SC1 Smart community infrastructures as an example of how such an upper ranking standard acts on the innovation formation as described (Ichikawa, 2013a; 2013b). Other examples can be found in the research of Paskaleva (2011) and Komninos (2011), for this research analyzes the smart city from an open innovation view. This research was conducted on the analysis of where the concept of "social innovation" is tacitly suggested, and furthermore suggests the joint possibility of both innovations. Moreover, it is shown that the stakeholder's function and role contribute to the favorable performance of the innovation.

The world population is currently slightly more urban than rural, since the level of world urbanization crossed the 50 per cent mark in 2009. Urban congestion causes diverse urban and social problems. Therefore the community infrastructure is essential to solve social problems. Economic growth is effective and essential to solving social problems such as poverty, pollution and public hygiene. Fundamental community infrastructures including energy, water, transportation, waste-management and ICT are essential to achieve economic growth. The ISO Standardization scope focuses on technical aspects of community-infrastructures including energy, water, transportation, waste and on ICT that support the operations and activities of communities. The concept of smartness is addressed in terms of performance relevant to technologically implementable solutions, in accordance with sustainable development in communities as elaborated in ISO/TC 268 (Table 4.) 
Table4 TC268 SC1 structure

\begin{tabular}{|l|l|}
\hline \multicolumn{1}{|c|}{ Membership } & \multicolumn{1}{c|}{ Country (Organization) } \\
\hline Secretariat & Japan (JISC) \\
\hline $\begin{array}{l}\text { Participating } \\
\text { countries (15) }\end{array}$ & $\begin{array}{l}\text { Argentina (IRAM); Austria (ASI); Canada (SCC); China (SAC); } \\
\text { Konmark (DS); France (AFNOR); Germany (DIN); } \\
\text { South Africa (SABS); Spain (AENOR); Sweden (SIS); } \\
\text { United Kingdom (BSI) }\end{array}$ \\
\hline $\begin{array}{l}\text { Observing } \\
\text { countries (10) }\end{array}$ & $\begin{array}{l}\text { Brazil (ABNT); Czech Republic (UNMZ); Egypt (EOS); } \\
\text { Fingapore (SFS); India (BIS); Malaysia (DSM); Norway (SN); } \\
\text { United Arab Emirates (ESMA) }\end{array}$ \\
\hline
\end{tabular}

Source: http://www.iso.org/iso/home/standards_development/list_of_iso_technical_ committees/iso_technical_committee_participation.htm?commid=656967 2013/05/06

\section{JSCA (Japan Smart Community Alliance)}

Japanese Government and Industry have formed a consortium with the goal of achieving social innovation in relation to TC268/SC1 Smart community infrastructures, dubbed the Japan Smart Community Alliance or JSCA (JSCA WEB SITE 2013). The New Energy and Industrial Technology Development Organization (NEDO ${ }^{1}$ ) established JSCA to strengthen collaboration among a wide range of concerned organizations and to also conduct activities of mutual interest, such as dissemination of information and preparation of roadmaps to achieve global standardization. International standardization is an important strategy for accomplishing these goals. JSCA has members from the electric power, gas, automobile, information and communications, electric machinery, construction and trading industries as well as the public sector and academia. Board members are comprised of eight companies, with MEC as a leading member. As the use of renewable energies such as photovoltaic and wind power is expected to increase, smart grids have been attracting worldwide attention as a means to achieve a stable renewable energy supply and to realize an effective and efficient electric grid system

1 NEDO was established as a semi-governmental organization in 1980 to promote the development and introduction of new energy technologies in JAPAN. Since its establishment, NEDO has undertaken technology development, demonstration projects and system improvement with the aim of improving Japan's global competitiveness and addressing social issues in an integrated manner. 
integrating information technology. It is expected that large smart grid markets will emerge in Europe, Asia and the United States and that initiatives toward a smart community will become more widespread. Therefore the Japan Smart Community Alliance was established in 2011 as practical parent organization to enable Japanese industry to participate in this market, and to tackle common issues on a national basis. Membership is limited to Japanese companies, and Foreign Companies that are partnered with Japanese companies. Membership is currently at 414 companies (at the time of April, 2013).

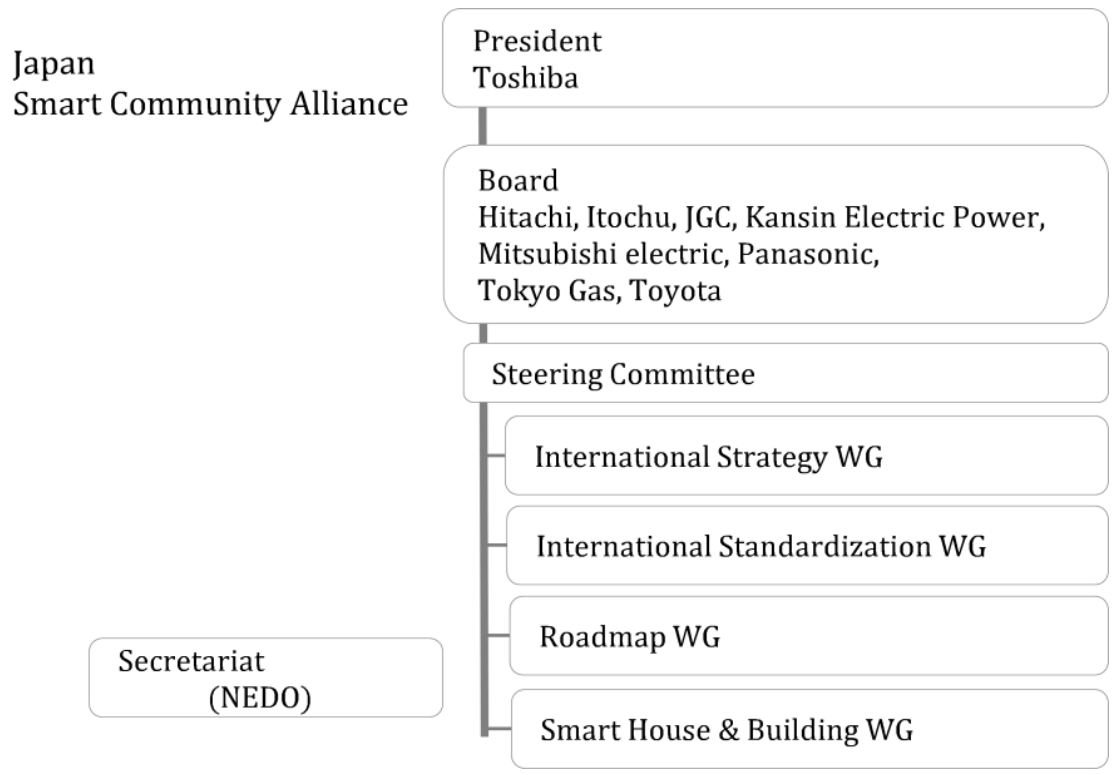

Figure3 JSCA organization

Source: Japan Smart Community Alliance; https://www.smart-japan. org/eglish tabid/103/Default.aspx2013/05/o6

JSCA's organizing companies inaugurated a discussion group aimed at international standardization pertaining to evaluation indices for smart cities and submitted a New Work Item Proposal (NWIP) to ISO from Japan. As a result, ISO established a new subcommittee, ISO/TC268/SC1 of which Japan was appointed secretariat to seek international standardization of evaluation indices for the smart urban infrastructure behind smart cities and promote the establishment of international infrastructure. No internationally agreed indices exist for comprehensive evaluation of whole cities including urban infrastructure such as water and sewage, transport, energy, telecoms, and waste treatment. Achieving international standardization of these evaluation indices 
will set standards for global infrastructure procurement, stimulating international trade in urban infrastructure. By playing an active secretariat role, Japan aims to create an environment where excellent urban infrastructure is evaluated appropriately and promote Japan's contribution to urban development in each country.

One international project that achieves such a purpose is the Delhi Mumbai Industrial Corridor (DMIC) which promotes the collaborative project in Japan and India.

\section{DMIC Projects}

DMIC is a state sponsored project implemented by the government of India for industrial development (Invest in Dholera WEG site 2013). The actual task of DMIC projects is to find significant expansion associated with Infrastructure as well as the Marketplace - including business groups as well as railroad, path, interface, air on-line - in the states along the route in the Corridor. DelhiMumbai Industrial Corridor is a jumbo infra-structure assignment of around USD 9 billion with the economic \& industrial techniques from Japan, covering an overall length of $1483 \mathrm{KMs}$ connecting the political capital and the business capital of India, i.e. Delhi and Mumbai. A Memorandum of Understanding agreement was signed on December 2006 between the Japanese vice Minister, Ministry of Economy, Trade and Industry (METI), and the Department of Industrial Policy \& Promotion DIPP). Projects of DMIC were offered to both Prime Ministers at the time of Premier Abe's touring to India on August 2007. METI of Japan and the Ministry of Commerce and Industry of India agreed on a list of prospective projects, with financing of USD 4.5 billion from Japan to India. The DMIC project is a Japan-India joint development project which aims to build a freight railway line connecting Delhi and Mumbai. Moreover, the project aims to develop infrastructures along the line, such as industrial areas, distribution centers, power plants, roads, sea ports, housing, and commercial facilities, mainly making use of private investments (Japan METI News Release 2012). Japanese companies including MEC are acquiring the projects for India, and the investment for the infrastructure and the system construction and exports are promoted in the DMIC international cooperative project. That is, DMIC is a social innovation of a social revolution. In addition, the member enterprise that joins JSCA will be able to achieve business growth by advancing the infrastructure maintenance of India. 


\section{Analysis}

\section{Value Creation (Table 6)}

\subsection{CC-Link}

Value creation of innovation is found in the R\&D process and patent development of network technologies. Next, it is found in the process where MEC played an important role in the CLPA establishment and in the process of the international standardization by CLPA. That is, it is possible to detect value creation in a series of processes until the consensus standard is approved. The network technology was developed first for in-house use in MEC and then converted into a patent. The innovation at that time was a closed innovation. Thus, it was an exclusive closed policy that held fast. However, to oppose system integrators in Europe and America and get rid of principal occupation vendors of single goods products, MEC selected the open policy and opened this technology to the public for free. MEC was centered as the partner. The external agency, CLPA, was established by a strategy involving five Japanese companies. CLPA played the role of an organization that spreads technology as well as a standard setting organization. Consensus standardization has advanced in the CLPA on the basis of CC-Link technology. CC-Link was adopted as an industry standard by SEMI to develop a standard proposal from CLPA to ISO and IEC. This led to international standardization. These series of processes are based on open innovation, based on open policy. The relationship between collaborative organizations, such as interchange of technology exchange information and chance of cooperation, is found in the CLPA member enterprises. Thus, the coupled type is formed for directionality of innovation. Moreover, value creation is considered to be the innovation task with partitioning to be performed by CLPA as an external agency.

\subsection{Smart Community Infrastructures}

Regarding the case of TC268/SC1 Smart community infrastructures, it is considered that in terms of innovation formation to be related to the composite standardization and the DMCA project. JSCA member enterprises originally own the in-house created technology, the patent, and the knowhow. These are resources from closed innovation. These have changed to the stage of open innovation by the outside agencies such as JSCA and ISO for the consensus standardization. Standardization works at the international project level but not the product level and the system level but at a high-ranking rank. A composite upper ranking standard is settled on in the outside agency with open oriented policy. There are a lot of stakeholders who take part in the standardization. Therefore, interface \& the interoperability effect and the network externality 
effect will greatly function. That is, the integrated standard system functions effectively in an industrial network structure of the vertical distribution type or the horizontal distribution type. As for the composite standard for a social innovation, the possibility of spreading on a large scale by a dominant trend to internationalize is much higher.

Table 6 Consensus standardization's innovation type

\begin{tabular}{|l|l|l|l|}
\hline \multirow{2}{*}{ Innovation } & \multicolumn{1}{|c|}{ Stage } & \multicolumn{1}{c|}{$\begin{array}{c}\text { Subordinate position } \\
\text { standard }\end{array}$} & \multicolumn{1}{c|}{$\begin{array}{c}\text { Upper ranking } \\
\text { standard }\end{array}$} \\
\cline { 2 - 4 } & Value creation stage & CC-Link & DMIC \\
\hline $\begin{array}{l}\text { Open / closed } \\
\text { innovation } \\
\text { (Generation Place) }\end{array}$ & $\begin{array}{l}\text { Open / closed } \\
\text { innovation (CLPA) }\end{array}$ & $\begin{array}{l}\text { Closed (In-house) } \\
\text { and open innovation } \\
\text { (JSCA, ISOTC268/SC1) }\end{array}$ \\
\hline idea
\end{tabular}

\section{Value capture (Table 7)}

\subsection{CC-Link}

Value capture of CC-Link has benefited not only MEC but also CLPA members. MEC first succeeded in spreading CC-Link through CLPA activities. Consequently, it expanded the FA business. Many Mitsubishi Electric product groups (controllers and servo motors) were adopted and introduced by vendors and consumers. Regarding the network technology system, rival companies in Europe and America are skilled in the vertical integration type system configuration, and strong closed innovation is maintained. To oppose this configuration, MEC established the vertical and horizontal distribution type system configurations in cooperation with the CLPA member group. This is judged to be based on open innovation. The CC-Link has resulted in collaborative benefits to user enterprises by offering a high-speed, highprecision communication network technology. Consequently, the user enterprises consist of 1, 500 companies or more (fiscal year 2010). Such a process denotes an open innovation, based on open policy. But it is a relation between group businesses and based on limited open policy. The directionality of innovation is a collaborative coupled type between interested organizations. 


\subsection{DMIC Projects}

The process of making to earnings of the MEC business is begun from the acquisition of the DMIC project. This is a stage where a social innovation is achieved in the economic value. The stakeholder of JSCA and ISO will construct the business model that conforms to the composite standard respectively. Regarding the case with DMIC projects, it is considered to be at the value capturing stage at an upper ranking level. MEC has top share domestically in industrial electrical machinery and apparatuses such as the FA equipment, the elevator, turbo-generators, and electric machine goods for vehicles, power semiconductors and space satellites. Sales are USD 37,948, 766,000 in 2013. Business Segments are Energy and Electric Systems (25.9\%), Industrial Automation Systems (22.7\%), Information and Communication Systems (12.8\%), Electronic Devices (4.0\%), Home Appliances (20.1\%) and others (http://www.mitsubishielectric.co.jp/). After handling the production of the turbo-generator in 1923, MEC has positively expanded business that supports the power infrastructure of Japan. MEC has a near $40 \%$ share for turbo-generators for thermal power generation and nuclear power generation, and is one of Japan's largest manufacturers. However, the Japanese market is mature with little room for growth. MEC should venture in to the emerging nations market and expand business accordingly. In addition, MEC is a single purpose product manufacturer, and it doesn't have the business model as a total system integrator.

Table 7 Consensus standardization's innovation type

\begin{tabular}{|l|l|l|l|}
\hline & \multicolumn{1}{|c|}{ Stage } & \multicolumn{1}{c|}{$\begin{array}{c}\text { Subordinate position } \\
\text { standard }\end{array}$} & \multicolumn{1}{c|}{$\begin{array}{c}\text { Upper ranking } \\
\text { standard }\end{array}$} \\
\cline { 2 - 4 } Innovation & Value capture stage & \multicolumn{1}{c|}{ CC-Link } & \multicolumn{1}{c|}{ DMIC } \\
\hline $\begin{array}{l}\text { Open / closed } \\
\text { innovation } \\
\text { (Generation Place) }\end{array}$ & Open innovation (CLPA) & $\begin{array}{l}\text { Open and social } \\
\text { innovation } \\
\text { (DMIC projects) }\end{array}$ \\
\hline knowledge, idea & $\begin{array}{l}\text { Outside-in / } \\
\text { inside-out flow }\end{array}$ & Both: coupled & Both: coupled \\
\hline Policy & Open / closed policy & Open policy (limited) & Open policy (limited) \\
\hline
\end{tabular}

The smart community business is an energy infrastructure where the supply side of energy and the demand side are achieved. Up to now, MEC has offered various products and systems in the field of power generation, power transmission, and the supply of electric power for power companies. Moreover, MEC assumes the power device technology and the power electronics technology to be a fundamental technology and has offered the product on the 
demand side in fields like traffic, building, factory, and home. However, it is insufficient only in the supply of an individual product as the business. Each product of MEC is organically connected by the ICT to attempt demand side and supply side integration and systematization for the whole energy business of MEC. It is necessary for the synthesis of a system to be based on a high ranking concept of a smart community. Therefore, it succeeded in the formation of the consortium with five companies in order to acquire the upper ranking standard project. MEC formed the Mitsubishi Group with four Mitsubishi related companies (Mitsubishi Heavy Industries Consortium) and acted to build such an elemental technology into the DMIC projects. This is an open innovation and open policy. But it is a relation between Mitsubishi group businesses, so it is a limited open policy. Five Mitsubishi group companies including MEC concluded the MOU with Tata Group in 2011, based on the of the feasibility study that investigated the formation of DMIC. The Mitsubishi group entrusted the smart community business to Gujarat state (seaside regional development, power generation, and urban traffic, etc.). A couple of reciprocal types were exchanged between the enterprises.

\section{Discussions}

\section{Findings}

In section $\mathrm{V}$, three cases with the ISO consensus standardization were analyzed. It is at the point that the value creation of the innovation is caused by the standardization that it is common to all. However, a high-ranking standard like a smart community can improve value creation that has more potential than the subordinate position level standard such as CC-Link. Because the standardization area is large and varied, a large number of stakeholders also become varied. Furthermore, the value creation is maximized by the consensus standardization for social innovation by open innovation, while the harvest possibility is extensible in the value capture stage.

Findings 1: The consensus standardization is an open innovation to which the enterprise creates value. Moreover, when it is the formal upper ranking standard, the possibility of maximizing the value creation increases.

Actually, an optional strategy of open innovation for the value capture in the consensus standard is abundant (Kajiura, 2012a 2012b). In the case of MEC, many products and systems can achieve economical earnings for the DMIC projects. In other words, business models from many businesses can be formed to MEC. In a word, standardizing the high rank at the stage of the value creation is higher than that of the subordinate position level standardization 
increasing the probability of the success in the business. The effect of the consensus standard is more effective than that of the de facto standard in the market formation and the expansion.

Findings 2: When the value creation is large, the possibility of the maximization of the value capture that achieves the earnings acquisition can be improved.

Moreover, the innovation directionality is the coupled type in the value creation as well as the value capture. The directionality of the open innovation held with ISO and consortia (CLPA, JSCA) is the coupled type. The reciprocal relations between the interested parties are achieved. This is a peculiar feature to the innovation in the consensus standardization.

Findings 3: The innovation of the consensus standardization is reciprocal in the stakeholder. The degree rises more than the subordinate position standardization as for high-ranking standardization.

\section{Presentation of Hypothesis}

This research relied on an innovation approach and clarified the features of the consensus standard. It is suggested that an open innovation model of the business be indispensable to achieve social innovation that is revived from a social revolution. Both innovations, supplement each other to create a dominant and compete innovation. The following hypotheses can be presented.

a) An open innovation of a corporate business functions positive in a social innovation.

b) The consensus standardization of upper level functions positively leads to social innovation success.

\section{Conclusion}

Three points can be enumerated as a meaning of this research.

First, this study works on a standard advanced research. The acquisition of the international standard by the enterprise is assumed to be an important task as an international business strategy. The consensus standardization is gaining power now, even though most standard research has been on the de facto standard. This study clarifies from the viewpoint of innovation theory, the consensus standardization. Secondarily, the present study develops the discussion about open innovation theory and presents the interface for social innovation. The possibility for open innovation and social innovation to supplement each other to achieve success is suggested. Finally, the limitation and the problem of the present study are described. The function of the 
consensus standard in the innovation was clarified. However, because the project in this study is ongoing, details of value capture are still being discovered. Moreover, it is uncertain if the research is a theme limited to consensus standards of ICT technologies, or applicable to additional fields and technologies.

\section{Acknowledgements}

This research paper is a part of the results reported on the research capital acquisition of Grant-in-Aid for Scientific Research (KAKENHI) (C), No. 21530417, by Japan Society for the Promotion of Science (JSPS), Innovation research of consensus standardization of diffusion and business earnings in ICT' (2009-2012), I wish to express my gratitude for co-researchers, Professor Yasuro Uchida (Toyama University) and Associate Professor Yoshinori Yasuda (Soka University). 


\section{References}

Cargill, C.F. (1989) Information Technology Standardization, Bedford: Digital Press MA.

Cargill, C.F. (1997) Open Systems, New Jersey: Prentice Hall.

Chandler, A.D., Jr. (1990) Scale and Scope: the Dynamics of Industrial Capitalism, Boston: Harvard University Press.

Chesbrough, H. (2003) Open Business Models, Boston: Harvard Business School Press.

Chesbrough, H. (2006) Open Business Models, Boston: Harvard Business School Publishing.

Chesbrough, H., Vanhaverbeke, W. and West, J. (eds.) (2006) Open Innovation, Researching a New Paradigm, New York: Oxford University Press.

Chesbrough, H.W. and Appleyard, M.M. (2007) Open innovation and strategy, California Management Review, 50(1), 57-76.

Chesbrough, H.W. and Crowther, A.K. (2006) Beyond high tech: early adopters of open innovation in other industries, R\&D Management, 36 (3), 229-236.

Chesbrough, H.W. and Garman, A.R. (2009) How open innovation can help you cope in lean times, Harvard Business Review, December, 87(12), 68-76.

Christensen, C.M. (1997) Innovator's dilemma, Boston: Harvard Business School Press.

Christensen, J.F. (2006) Whither Core Competency for the Large Corporation in an Open Innovation World?. in Chesbrough, H., Vanhaverbeke, W. and West, J. (eds.), Open Innovation, Researching a New Paradigm, 35-61, New York: Oxford University Press.

De Vries, H.J. (1999) Standardization: A Business Approach to the Role of National Standardization Organization, Boston: Kluwer Academic Publishers.

Enkel, E., Gassmann, O. and Chesbrough, H. (2009) Open R\&D and open innovation: exploring the phenomenon, R\&D Management, 39(4), 311-316.

Etoh, M. (2007) IPR and Standardization, in Kajiura, M. (ed.), International Business and Technological Standards, 182-229, Tokyo: Bunshindo. (in Japanese)

Etoh, M. (2008) What is Consensus-Based Standards, in Shintaku, J. and Etoh, M. (eds.), Strategic Use of Consensus-Based Standards, 1-35, Tokyo: Nihon Keizai Shinbunsya Publishing. (in Japanese)

Fujii, T. (2012) Non-Market Strategy, Tokyo: Tokyo-Keizai Shinposha. (in Japanese)

Goldsmith, S. et al. (2010) The Power of Social Innovation, San Francisco: Jossey-Bass. Herzog, P. (2008) Open and Closed Innovation $1^{\text {st }}$ Edition, Wiesbaden: Gabler Verlag. Herzog, P. (2008) Open and Closed Innovation $2^{\text {nd }}$ Edition, Wiesbaden: Gabler Verlag.

Hong, Y.S. (2012) Modes of combinative innovation : case of Samsung electronics, Asian Journal of Innovation and Policy, 1(2), 219-239.

Ichikawa, Y. (2013a) World Environmental Standardization War, Nikkei Business online, http://business.nikkeibp.co.jp/article/report/20130108/24 1962/2013/4/25acacce. (in Japanese)

Ichikawa, Y. (2013b) ISO/TC268/SC1 - Smart Community Infrastructures, http://www. itu. int/ en/ ITU-T/ jca/ictcc/ Documents/docs-2013/YoshiakiIchi kawa_JCA_Feb 2013.pdf 
Invest In Dholera WEG site, DMIC Project, http://www.investindholera.com/D

MIC-projects. html 2013/05/01 access.

ISO web site, http://www.iso.org/iso/home.html.2013/05/01acsess.

Jakobs, K. (ed.) (2000) Information Technology Standards and Standardization: A Global Perspective, Idea Group Publishing, New York.

Jakobs, K. (ed.) (2005) Advanced Topics in Information Technology Standards and Standardization Research, New York: Idea Group Publishing.

Japan METI (2012) November, http://www.meti.go.jp/press/2012/11/20121119 003/20121119003-1.pdf.

JSCA Web site, https://www.smart-japan.org/home/2013/05/05access.

Kajiura, M. (2005) IT Standard, Tokyo: Bunshindo. (in Japanese)

Kajiura, M. (2008) ICT international standard consortia, JAFTAB Journal, (47), 156166. (in Japanese)

Kajiura, M. (2010) The strategic consortia movement in standardization, International Journal of Manufacturing Technology and Management, 21(3/4), 324-339.

Kajiura, M. and Uchida Y. (2010) Strategy of standardization in AIT, International Journal of Automated Identification Technology, 2(1), 15-21.

Kajiura, M. (2012a) Open innovation of consensus standard-cases of business model creation in ICT, International Journal of Enterprises Network Management, 5(2), 126-143.

Kajiura, M. (2012b) Open innovation in the IT strategic business models of standards and patents, International Journal of Logistics, Economics and Globalisation, 4(1/2), 99-116.

Kajiura, M. (2013) ICT Consensus Standard, Tokyo: Bunshindo. (in Japanese)

Kania, J and Kramer, M. (2011) Collective impact, Stanford Social Innovation Review, Winter, 9(1), 35-41.

Komninos, N. (2011) Intelligent cities: variable geometries of special intelligence, Intelligent Buildings International, 3(3), 172-188.

Kotler, P. and Lee, N.R. (2009) Up and Out of Poverty: The Social Marketing Solution, Pennsylvania: Wharton School Publishing.

London, T. and Hart, S.L. (2011) Next Generation Business Strategies for the Base of the Pyramid, New Jersey: Pearson Education, Inc.

Mumford, M. (2002) Social innovation: ten cases from Benjamin Franklin, Creativity Research Journal, 14(2), 253-266.

Murry, R., Caulier, J.and Mulgan, G. (2010) The Open Book of Social Change, Oxford: Oxford University Press.

Moon, S.W. (2011) What determines the openness of Korean manufacturing firms to external knowledge?, Journal of Korea Technology Innovation Society, 14(3), 405430.

Nicholls, A. and Murdock, A. (eds.) (2012) Social Innovation, Basingstoke: Palgrave Macmillan.

Paskaleva, K.A. (2011) The smart city: a nexus for open innovation, Intelligent Buildings International, 3(3), 153-171.

Prahalad, C.K. (2005) The Fortune at the Bottom of the Pyramid, Chicago: Wharton Publishing.

Porter, M.E. (1986) The technological dimension of competitive strategy, Rosenbloom, 
R.S. (ed.), Research on technological innovation, management and policy, A Research Annual, JAI Press, 1, 1-33.

Porter, M.E. and Kramer, M. (2011) Creating shared value, Harvard Business Review, January-February, 2-12.

Sanders, T.B.R. (ed.) (1972) The Aims and Principles of Standardization., Geneva: ISO.

Saul , J. (2011) Social Innovation, San Franncisco: Jossey-Bass.

Scumpeter, J.A. (1912) Theorie der wirtschaftlichen Entwicklung, Duneker \& Humblot: Berlin.

Shibata, T. (2000) De facto standard strategy in the age of multimedia. (in Japanese)

Sintaku, J., Kai, J.Y. and Shibata, T. (eds.) (2000) The Essence of De Facto Standard, 41-54,. Tokyo: Yuhikaku. (in Japanese)

Shintaku, J. and Etoh, M. (eds.) (2008) Strategic Use of Consensus Based Standards, Ch. 1, 3, 5, Tokyo: Nihon Keizai Shinbunsha. (in Japanese)

Simcoe, T.S. (2006) Open Standards and Intellectual Property Rights. Chesbrough, H., Vanhaverbeke, W. and West, J. (eds ), Open Innovation, Researching a New Paradigm, 161-183, New York: Oxford University Press.

Takeda, S. (2008) A study on the formation of standards through global competition by multinationals, MNE Academy Journal, 1, 31-48. (in Japanese)

Teece, D. (1986) Profiting from technological innovation: implication for integration, collaboration, and public policy, Research Policy, 15, 285-305.

Teece, D. et al. (1997) Dynamic capabilities and strategic management, Strategic Management Journal, 18(7), 509-533.

Tokuda, A., Tatsumoto, H. and Ogawa, K. (2011) Open Innovation System, Tokyo: Koyoshobo. (in Japanese)

Verman, L.C. (1973) Standardization: A New Discipline, Ardon Books, Hamden: CT.

Yamada, H. (1997) Competitive Strategies for De Facto Standard, Tokyo: Nihon Keizai Shinbunsha. (in Japanese)

Yamada, H. (2009) Standardization and IPR strategy in telecommunication industry, Chizai Kanri, 59(3), 263-271. (in Japanese)

Yoon, B.U. and Lee, S.J. (2010) Open innovation models in SMEs, Journal of Korea Technology Innovation Society, 13(1), 160-183. 